\title{
Cardiac Arrhythmia Related to Remdesivir in COVID-19
}

MIGUEL RODRÍGUEZ GUERRA (1)

CHRISTIAN MENDOZA

SAMEER KANDHI

HAOZHE SUN

MUHAMMAD SAAD

TIMOTHY VITTORIO

*Author affiliations can be found in the back matter of this article

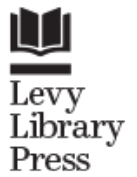

Press

\section{ABSTRACT}

Background: Remdesivir has shown a positive impact on patient's clinical improvement with COVID-19 and could represent and future viral infections.

Results: 16 out of 37 patients presented bradycardia, 4 of these patients had QTC > 450 ms. Infusion for 3 days or more of infusion had a higher incidence of bradycardia (12 vs 4 patients). Overall, patients without bradycardia had a longer hospitalization (20.5 vs 15.5 days); 7 patients died, 2 of them had bradycardia.

Conclusion: Our results have shown clear evidence of bradycardia after remdesivir infusion. Prospective, double-blinded, and randomized studies with an evident representative sample size with various ethnicities and races are highly needed earlier than later to establish these important findings.

\section{CORRESPONDING AUTHOR:}

Miguel Rodriguez-Guerra, MD

Internal Medicine PGY-3, BronxCare Hospital Center, Department of Medicine, 1650 Selwyn Ave, 10th Floor, Bronx, NY 10457, US

m.rodriguezg.md@gmail.com

KEYWORDS:

Arrhythmia; COVID; Bradycardia

\section{TO CITE THIS ARTICLE:}

Rodriguez-Guerra M, Mendoza C, Kandhi S, Sun H, Saad M, Vittorio T. Cardiac Arrhythmia Related to Remdesivir in COVID-19. ISMMS Journal of Science and Medicine. 2021; 1(2): 15, pp. 1-6. DOI: https:// doi.org/10.29024/ijsm.64 


\section{INTRODUCTION}

Remdesivir is a nucleoside analog used against several RNA-dependent RNA polymerase viruses, affecting their replication and resulting in the early termination of the viral cycle, and it has shown a positive impact in clinical improvement of patients with COVID-19 [1, 2]. There is clear evidence of the broad-spectrum antiviral activity of remdesivir via mediation of RNA synthesis inhibition in coronaviruses [3]. However, this medication has been associated with cardiac arrhythmias and events after its administration [4, 5].

The mechanism of the adverse cardiac effects of this drug is not clearly understood, but there is a hypothesis positing that the cumulative dose effects could lead to toxicity, conduction defects, ECG abnormalities (prolongation of QTc, ventricular arrhythmia, cardiac arrest), and cardiomyopathy [6].

Remdesivir is a potential therapeutic measure in present and future viral infections. Recently, we faced one of the worst pandemics in history, and possible recurrent waves could be expected, which is why we performed this retrospective study to establish the relationship of remdesivir with cardiac arrhythmias.

\section{OBJECTIVE}

To establish the relationship of remdesivir with cardiac arrhythmias in COVID-19, as well as to determine its relationship with cardiac arrest in COVID-19.

\section{METHOD}

This is a descriptive retrospective study establishing the relationship of remdesivir with cardiac arrhythmias and also determining the relationship between remdesivir and cardiac arrest. The data were collected retrospectively for patients in the period from May to November 2020. The process of the collection was based on a questionnaire inspired by our variables. The literature review was based on the analysis of 20 original studies published in prominent medical journals regarding remdesivir side effects and remdesivir treatment options for COVID-19 infection.

\section{VARIABLES}

The variables studied and evaluated in this study are age $(18-44,45-65,>65)$, sex (male, female), days of remdesivir infusion ( $1-2,3-5,>5$ days), BMI $(<29.9,>30)$, cardiovascular (CV) and metabolic factors (hypertension (HTN), dyslipidemia (DLP), cardiovascular accident (CVA), peripheral vascular disease, congestive heart failure, endocarditis, diabetes mellitus (DM), thyroid pathology, previous CV procedures), history of arrhythmia (atrial, ventricular, none), familial CV history (prolonged QTC, sudden death, congenital cardiomyopathy, arrhythmia, Brugada, myocardial infarction (MI), congestive heart failure, coronary artery disease (CAD)), ECG findings on admission (atrial fibrillation (Afib), block grade 1, block grade 2, block grade 3, evidence of MI (previous), evidence of acute MI (AMI), complete right bundle branch block (CRBBB), complete left bundle branch block (CLBBB), ventricular fibrillation or ventricular tachycardia, torsade, Afib or atrial flutter (Aflut), fascicular block, pericarditis, left ventricular hypertrophy (LVH), electrocardiogram (ECG) events during hospitalization (Afib (uncontrolled), multifocal atrial tachycardia (MAT), supraventricular tachycardia, ventricular fibrillation, ventricular tachycardia, other), cardiac events (cardiac arrest, respiratory arrest, none), and death during admission (yes, no).

\section{INFORMATION PROCEDURE AND STATISTICAL ANALYSIS}

During the questionnaire analysis, the supervisors of the study reviewed each questionnaire and compared it with our electronic medical record system, verifying the correct collection of the data. A total of 43 records were reviewed. Our analysis was verified by $c^{2} i^{2}, p=0.04$.

\section{INCLUSION CRITERIA}

Adult patients who received remdesivir for COVID-19 in the established period. 


\section{RESULTS}

A total of 43 patients (pts) were studied, of whom we excluded six because they did not complete the first dose of the medication studied. Our analysis of 37 pts was composed of 19 males and 18 females, and the predominant age group was 65 years old (yo) or older, with $56.76 \%$ (21 pts), followed by $45-65$ yo, with $29.73 \%$ (11), and then $18-45$ yo, representing $13.51 \%$ (5) (Table 1). The Hispanic population was the biggest, with $91.9 \%$ (34 pts), followed by the African American (AA) population, with 2.7\% (1), and then others, with $5.40 \%(2)$.

\begin{tabular}{ll}
\hline AGE & PATIENTS \\
\hline$>65$ & 21 \\
$45-65$ & 11 \\
$18-45$ & 5 \\
\hline
\end{tabular}

The most common CV factor present in our patients was HTN, with $72.97 \%$ (27 pts), followed by DM, with $48.65 \%$ (18); obesity, with $40.54 \%$ (15); DLP, with $32.43 \%$ (12); and others (Table 2).

\begin{tabular}{ll}
\hline CV RISK & PATIENTS $(N=37)$ \\
\hline HTN & 27 \\
\hline DM & 18 \\
\hline Obesity & 15 \\
\hline DLP & 12 \\
\hline CKD $\geq 3$ & 11 \\
\hline CAD & 2 \\
\hline Other & 2 \\
\hline H. failure & 1 \\
\hline CKD $\leq 2$ & 0 \\
\hline ESRD & 0 \\
\hline
\end{tabular}

Electrocardiographic events during hospitalization were not documented in our patients, but a total of $43.24 \%$ (16 pts) presented bradycardia after remdesivir administration, and no significant difference between sexes was observed ( 8 males vs 7 females). Regarding the duration of the infusion in these patients, we observed that patients with 3 days or more, or $75 \%$ (12 out of 16 pts), versus less than 3 days, or $25 \%$ (4), presented bradycardia (Table 3). Four of the 16 pts with at least 3 days of treatment were noted to have QTc $>450$ ms during their admission. A total of 2 pts in this group died, and one required re-hospitalization.

\begin{tabular}{lll}
\hline & PATIENTS & BRADYCARDIA \\
\hline >5 days & 6 & 2 \\
\hline 3-5 days & 27 & 10 \\
\hline 1-2 days & 4 & 3 \\
\hline$<1$ day* & 6 & 0 \\
\hline Total & $43->37$ & 15 \\
\hline
\end{tabular}

Only 1 pt who presented bradycardia was receiving a beta-blocker, and only 1 pt was receiving sedatives.

Patients without bradycardia had a longer hospitalization (20.5 vs 15.5 days) and higher mortality (5 vs 2 pts). Overall, 18.92\% (7 pts) died, and prolonged hospitalization (10-50 days) was noted for $100 \%$ of them (10-50 days). All had DM and HTN, 3 pts had thyroid disease,
Table 1 Age Groups.

Table 2 Cardiovascular Risk Factors.

CKD, chronic kidney disease; ESRD, end-stage renal disease.

Table 3 Bradycardia After Remdesivir Infusion.

* Excluded. 
4 were obese, and 4 had QTc > 450 ms. Only 4 pts were noted to require re-hospitalization (within 90 days) at our center.

\section{DISCUSSION}

Remdesivir's mechanism is based on the inhibition of viral replication via an adenosine analog that becomes incorporated into the virus and inhibits viral replication by early termination of its cycle [7].

The efficacy of this medical agent is related to its affinity for viral RNA polymerase compared with human mitochondrial RNA polymerase (h-mtRNAP). Based on a literature review of papers on the Ebola pandemic, remdesivir's affinity for viral polymerases is $>500$ times that for $h-m t R N A P$ [8]. However, there is an association between its mechanism of action and cardiotoxicity via an increase in mitochondrial oxidative/nitrative stress [9]. Mouse models also showed a reduction in viral load and lung infection after remdesivir was administered [10].

Although the SOLIDARITY trial did not show a difference in mortality with remdesivir, lopinavir or ritonavir hydroxychloroquine, and interferon [11], the administration of remdesivir $200 \mathrm{mg}$ as a loading dose followed by $100 \mathrm{mg}$ daily for the next 10 days showed a clinical improvement in SARSCoV-2 $[12,13]$. The most common side effects of remdesivir that have been identified are increased hepatic enzymes, diarrhea, anemia, rash, renal impairment, and hypotension [14, 15, 16, 17$]$.

Another side effect, which could be missed, is electrocardiographic changes [18], including cardiac arrhythmias, but based on the literature, bradycardia and hypotension are more common than QT prolongation [19, 20, 21, 22]. Marked sinus bradycardia after the initiation of remdesivir and its resolution after stopping the drug have been evident [23] and suggest attention to the CV adverse effects from this and other drug classes to avoid potentially fatal side effects and improve the outcome of our patients [24]. A randomized controlled trial that included 233 patients showed cardiac arrest during remdesivir therapy, which was not noted in the placebo group [25].

Our review exposed the potential cardiac adverse side effects and events that could be a consequence of remdesivir administration, and our analysis showed a tendency toward bradycardia related to the duration of the treatment and not necessarily related to the history of prolonged QTC or the severity of the disease in our patients. However, we have observed the substantial benefit of this therapy in the current pandemic that we are facing from the infectious, pulmonary, and critical care points of view. The benefit versus risk always has to be discussed, and the best benefit to our patients has to be prioritized.

The systemic inflammatory response and the acute state in severe COVID-19 could also predispose patients to cardiac injury, including conduction disease, but in our analysis, bradycardia was evident in the patients who received remdesivir infusion at our medical center despite the severity of their condition.

\section{CONCLUSIONS}

In conclusion, our results have shown clear evidence of bradycardia after remdesivir infusion. Prospective, double-blinded, and randomized studies with alarger sample size with various ethnicities and races are highly needed earlier rather than later to confirm these important findings.

\section{ADDITIONAL FILE}

The additional file for this article can be found as follows:

- Supplementary file. Sociodemographic Questionnaire for Remdesivir Project. DOI: https:// doi.org/10.29024/ijsm.64.s1

\section{COMPETING INTEREST}

The authors have no competing interests to declare. 


\section{AUTHOR AFFILIATIONS}

\section{Miguel Rodríguez Guerra (D) orcid.org/0000-0002-7047-6077}

BronxCare Health System, Icahn School of Medicine at Mount Sinai, Department of Internal Medicine, Bronx, NY, US

\section{Christian Mendoza}

BronxCare Health System, Icahn School of Medicine at Mount Sinai, Department of Internal Medicine, Bronx, NY, US

\section{Sameer Kandhi}

BronxCare Health System, Icahn School of Medicine at Mount Sinai, Department of Internal Medicine, Bronx, NY, US

\section{Haozhe Sun}

BronxCare Health System, Icahn School of Medicine at Mount Sinai, Department of Internal Medicine, Bronx, NY, US

\section{Muhammad Saad}

BronxCare Health System, Icahn School of Medicine at Mount Sinai, Division of Cardiology, Bronx, NY, US

Timothy Vittorio

BronxCare Health System, Icahn School of Medicine at Mount Sinai, Division of Cardiology, Bronx, NY, US

\section{REFERENCES}

1. Beigel JH, Tomashek KM, Dodd LE, Mehta AK, Zingman BS, Kalil AC, Hohmann E, Chu HY, Luetkemeyer A, Kline S, de Castilla DL, Finberg RW, et al. Remdesivir for the Treatment of Covid-19 — Final Report. N Engl J Med. 2020; 383: 1813-1826. DOI: https://doi.org/10.1056/NEJMoa2007764

2. Rodriguez-Guerra M, Jadhav P, Vittorio TJ. Current treatment in COVID-19 disease: a rapid review. Drugs in Context. 2021; 10: 2020-10-3. DOI: https://doi.org/10.7573/dic.2020-10-3

3. Gordon CJ, Tchesnokov EP, Woolner E, Perry JK, Feng JY, Porter DP, Götte M. Remdesivir is a direct-acting antiviral that inhibits RNA-dependent RNA polymerase from severe acute respiratory syndrome coronavirus 2 with high potency. J Biol Chem. 2020 May 15; 295(20): 6785-6797. DOI: https://doi.org/10.1074/jbc.RA120.013679

4. Gupta AK, Parker BM, Priyadarshi V, et al. (October 24, 2020) Cardiac Adverse Events With Remdesivir in COVID-19 Infection. Cureus. 12(10): e11132. DOI: https://doi.org/10.7759/cureus.11132

5. Barkas F, Styla CP, Bechlioulis A, Milionis H, Liberopoulos E. Sinus Bradycardia Associated with Remdesivir Treatment in COVID-19: A Case Report and Literature Review. J. Cardiovasc. Dev. Dis. 2021; 8: 18. DOI: https://doi.org/10.3390/jcdd8020018

6. Long B, et al. Cardiovascular complications in COVID-19. The American Journal of Emergency Medicine. 2020. DOI: https://doi.org/10.1016/j.ajem.2020.04.048

7. Rodriguez-Guerra M, Jadhav P, Vittorio TJ. Current treatment in COVID-19 disease: a rapid review. Drugs in Context. 2021; 10: 2020-10-3. DOI: https://doi.org/10.7573/dic.2020-10-3

8. Tchesnokov EP, Feng JY, Porter DP, Götte M. Mechanism of Inhibition of Ebola Virus RNA-Dependent RNA Polymerase by Remdesivir. Viruses. 2019 Apr 4; 11(4): 326. DOI: https://doi.org/10.3390/v11040326

9. Varga ZV, Ferdinandy P, Liaudet L, Pacher P. Drug-induced mitochondrial dysfunction and cardiotoxicity. Am J Physiol Heart Circ Physiol. 2015 Nov; 309(9): H1453-67. DOI: https://doi. org/10.1152/ajpheart.00554.2015

10. Pruijssers AJ, George AS, Schäfer A, et al. Remdesivir inhibits SARS-CoV-2 in human lung cells and chimeric SARS-CoV expressing the SARS-CoV-2 RNA polymerase in mice. Cell Rep. 2020; 32: 107940. DOI: https://doi.org/10.1016/j.celrep.2020.107940

11. Fosbøl EL, Butt JH, Østergaard L, et al. Association of angiotensin-converting enzyme inhibitor or angiotensin receptor blocker use with COVID-19 diagnosis and mortality. JAMA. 2020; 324(2): 168-177. DOI: https://doi.org/10.1001/jama.2020.11301

12. Beigel JH, Tomashek KM, Dodd LE, et al. Remdesivir for the treatment of Covid-19 - preliminary report. N Engl J Med. 2020; 383: 1813-1826. DOI: https://doi.org/10.1056/NEJMoa2007764

13. Wang Y, Zhang D, Du G, et al. Remdesivir in adults with severe COVID-19: a randomized, doubleblind, placebocontrolled, multicentre trial. Lancet. 2020; 395(10236): 1569-1578. DOI: https://doi. org/10.1016/S0140-6736(20)31022-9

14. Musa A, Pendi K, Hashemi A, et al. Remdesivir for the treatment of COVID- 19: a systematic review of the literature. West J Emerg Med. 2020; 21: 737-741. DOI: https://doi.org/10.5811/ westjem.2020.5.47658

15. Liang C, Tian L, Liu Y, et al. A promising antiviral candidate drug for the COVID-19 pandemic: $\mathrm{a}$ mini-review of remdesivir. Eur J Med Chem. 2020; 201: 112527. DOI: https://doi.org/10.1016/j. ejmech.2020.112527

16. Humeniuk R, Mathias A, Cao H, et al. Safety, tolerability, and pharmacokinetics of Remdesivir, an antiviral for treatment of COVID-19, in health subjects. Clin Transl Sci. 2020; 13: 896-906. DOI: https://doi.org/10.1111/cts.12840 
17. Javorac D, Grahovac L, Manic L, et al. An overview of the safety assessment of medicines currently used in the COVID-19 disease treatment. Food Chem Toxicol. 2020; 144: 111639. DOI: https://doi. org/10.1016/j.fct.2020.111639

18. Grein J, Ohmagari N, Shin D, Diaz G, Asperges E, Castagna A, Feldt T, Green G, Green ML, Lescure FX, Nicastri E, Oda R, Yo K, Quiros-Roldan E, Studemeister A, Redinski J, Ahmed S, Bernett J, Chelliah D, Chen D, Chihara S, Cohen SH, Cunningham J, D'Arminio Monforte A, Ismail S, Kato H, Lapadula G, L'Her E, Maeno T, Majumder S, Massari M, Mora-Rillo M, Mutoh Y, Nguyen D, Verweij E, Zoufaly A, Osinusi AO, DeZure A, Zhao Y, Zhong L, Chokkalingam A, Elboudwarej E, Telep L, Timbs L, Henne I, Sellers S, Cao H, Tan SK, Winterbourne L, Desai P, Mera R, Gaggar A, Myers RP, Brainard DM, Childs R, Flanigan T. Compassionate Use of Remdesivir for Patients with Severe Covid19. N Engl J Med. 2020 Jun 11; 382(24): 2327-2336. DOI: https://doi.org/10.1056/NEJMoa2007016

19. Barlow A, Landoff K, Barlow B, Yeung S. Review of emerging pharmacotherapy for the treatment of coronavirus disease 2019. Pharmacotherapy. 2020; 40: 416-437. DOI: https://doi.org/10.1002/ phar.2398

20. Grein J, Ohmagari N, Shin D, et al. Compassionate use of Remdesivir for patients with severe Covid19. N Engl J Med. 2020; 382: 2327-2336. DOI: https://doi.org/10.1056/NEJMc2015312

21. Li Z, Wang X, Cao D, Sun R, Li C, Li G. Rapid review for the anti-coronavirus effect of remdesivir. Drug Discov Ther. 2020; 14: 73-76. DOI: https://doi.org/10.5582/ddt.2020.01015

22. Mehta M, Shyh G. A review of Remdesivir for COVID- 19: data to date. Cardiol Rev. 2020; 28: 332-334. DOI: https://doi.org/10.1097/CRD.0000000000000337

23. Gubitosa JC, Kakar P, Gerula C, Nossa H, Finkel D, Wong K, Khatri M, Ali H. Marked Sinus Bradycardia Associated With Remdesivir in COVID-19: A Case and Literature Review. JACC: Case Reports. 2020; 2(14): 2260-2264, ISSN 2666-0849. DOI: https://doi.org/10.1016/j.jaccas.2020.08.025

24. Gupta AK, Parker BM, Priyadarshi V, Parker J. Cardiac Adverse Events With Remdesivir in COVID19 Infection. Cureus. 2020; 12(10): e11132. Published 2020 Oct 24. DOI: https://doi.org/10.7759/ cureus.11132

25. Wang Y, Zhang D, Du G, Du R, Zhao J, Jin Y, Fu S, Gao L, Cheng Z, Lu Q, Hu Y, Luo G, Wang K, Lu Y, Li H, Wang S, Ruan S, Yang C, Mei C, Wang Y, Ding D, Wu F, Tang X, Ye X, Ye Y, Liu B, Yang J, Yin W, Wang A, Fan G, Zhou F, Liu Z, Gu X, Xu J, Shang L, Zhang Y, Cao L, Guo T, Wan Y, Qin H, Jiang Y, Jaki T, Hayden FG, Horby PW, Cao B, Wang C. Remdesivir in adults with severe COVID-19: a randomised, double-blind, placebo-controlled, multicentre trial. Lancet. 2020 May 16; 395(10236): 1569-1578. DOI: https://doi.org/10.1016/S0140-6736(20)31022-9
Rodriguez-Guerra et al. ISMMS Journal of Science and Medicine

DOI: $10.29024 / \mathrm{ijsm} .64$
TO CITE THIS ARTICLE: Rodriguez-Guerra M, Mendoza C, Kandhi S, Sun H, Saad M, Vittorio T. Cardiac Arrhythmia Related to Remdesivir in COVID-19. ISMMS Journal of Science and Medicine. 2021; 1(2): 15, pp. 1-6. DOI: https:// doi.org/10.29024/ijsm.64

Submitted: 18 May 2021

Accepted: 04 June 2021

Published: 23 June 2021

\section{COPYRTGHT:}

(c) 2021 The Author(s). This is an open-access article distributed under the terms of the Creative Commons Attribution 4.0 International License (CC-BY 4.0), which permits unrestricted use, distribution, and reproduction in any medium, provided the original author and source are credited. See http://creativecommons.org/ licenses/by/4.0/.

ISMMS Journal of Science and Medicine is a peer-reviewed open access journal published by Levy Library Press. 